\title{
低炭素鋼の疲労き裂発生過程に及ばすひずみ時効の影響* （電顕連続観察による検討）
}

\author{
高尾 健 一** 西谷弘 信 ${ }^{* * *}$ 坂 口 英 信 $* * * *$ \\ Effect of Strain Aging on Fatigue Crack Initiation Process \\ of Low Carbon Steel \\ (Successive Observations by SEM)
}

by

\author{
Ken-ichi TAKAO \\ (Faculty of Science and Engineering, Saga University, Saga) \\ Hironobu NISITANI \\ (Faculty of Engineering, Kyushu University, Fukuoka) \\ and Hidenobu SAKAGUCHI \\ (Faculty of Science and Engineering, Saga University, Saga)
}

\begin{abstract}
Rotating bending fatigue tests have been carried out on smooth specimens of an annealed aluminum-killed steel, an annealed rimmed steel and a low temperature quenched rimmed steel. Successive observations on the surfaces of the specimens and fractographic observations have been made by SEM with special attention being given to the starting points of fatigue cracking, in order to investigate the effect of strain aging on fatigue crack initiation process.

The main results obtained are as follows;

(1) A low temperature quenched rimmed steel, which has the highest strain aging ability, had a higher resistance to initiation and propagation of fatigue cracks and had an about $50 \%$ higher fatigue limit comparing with other two steels. However, no qualitative difference was recognized among the steels in the process of initiation of a crack when the crack size was about the size of a grain. This process is such that the region, which is to become a crack in the future, is damaged as a whole with little increase in size at the specimen surface and gradually turns into a crack. Moreover, this process is essentially different from the later crack propagation process. Fractography of the initial stage of fatigue cracking also seems to support the above statement.

(2) Non-propagating microcracks were observed on the unbroken specimen surface subjected to more than $10^{7}$ cycles at the respective fatigue limit. Although some of them remained within the grain, the largest one propagated into neighboring grains and then stopped propagating.
\end{abstract}

キー・ワード：低炭素鋼，ひずみ時効，疲労き裂発生過程，微視的停留き裂

(Received Mar. 7, 1980)

\section{1 緒言}

低炭素鋼の疲労挙動に及ぼすひずみ時効の影響につ (て, 疲労限度に対するだけでなく, 過大, 過小応力 効果, コーキシング効果, 二段重複応力下の疲労, き 裂進展等に対しても多くの研究がなされている. しか しながら高サイクル疲労に和ける疲労破壊は材料表面

\footnotetext{
* 原稿受理 昭和55年 3 月 7 日

** 正会員 佐賀大学理工学部 佐賀市本庄町

*** 正会員 九州大学工学部 福岡市東区箱崎町

**** 学生会員 佐賀大学大学院 佐賀市本庄町
}

に発生した 1 個ないし数個のき裂が発生, 伝ぱして起 ることを考慮して, 破断の起点にまでさかのぼって微 視的さ裂の挙動に及ぼすひずみ時効の影響を調べた研 究は少く, 特に電子顕微鏡による連続観察は見当らな いようである。

本研究は，このような点を考慮して，ひずみ時効能 の異る低炭素鋼（疲労部門委員会の共同研究用材料, リムド鋼CH10R和よびアルミニウムキルド鋼CH10A) の回転曲げ疲労試験を行い,レプリカ法により疲労き 裂発生の起点に注目して, 疲労過程, 特にき裂発生過 
程に及ぼすひずみ時効の影響を走査電子蹎微鏡(SEM) による表面連続観察および初期疲労破面の観察を通じ て検討したものである.

\section{2 材料, 試験片および実験方法}

用いた材料は低炭素鋼（リムド鋼 CH10R，アルミ ニウムキルド鋼 $\mathrm{CH} 10 \mathrm{~A}$ でどちらも直径 $13 \mathrm{~mm}$ ) 圧 延丸棒である. Table I〜III にそれぞれ化学成分, 熱 処理条件と試験片作製手順，および熱処理後の機械的 性質を示す. CH10R の平均結晶粒径は約 $25 \mu \mathrm{m}$, CH10A のそれは約 $32 \mu \mathrm{m}$ である. Fig. 1 亿試験片 形状を示す. 浅い切欠さを付けたのは疲労被害を受け る領域を局限するためである. 切欠さ係数は小さい (CH10A 焼なまし材の回転曲げ疲労に和ける切欠き係 数は約1.06である) ので，本試験片では実質的には平 滑試験片とみなし得る. 試験片に加える応力は切欠き

Table I. Chemical composition. (\%)

\begin{tabular}{|c|c|c|c|c|c|c|}
\hline Material & C & $\mathrm{Si}$ & $\mathrm{Mn}$ & $P$ & $S$ & $\mathrm{Al}$ \\
\hline $\begin{array}{l}\text { Al-killed } \\
\text { steel }\end{array}$ & 010 & 0.015 & 0.46 & 0012 & 0016 & 0028 \\
\hline $\begin{array}{l}\text { Rimmed } \\
\text { steel }\end{array}$ & 010 & 0.001 & 043 & 0027 & 0.027 & 0.001 \\
\hline
\end{tabular}

Table II. Procedure for preparation of specimens.

\begin{tabular}{l|l}
\hline $\begin{array}{l}\text { Al-killed } \\
\text { steel (A.A) }\end{array}$ & $\begin{array}{l}920^{\circ} \mathrm{C}, 1 \mathrm{hr}, \text { F.C. } \rightarrow \text { Machining } \rightarrow \\
700^{\circ} \mathrm{C}, 1 \mathrm{hr}, \text { F.C. (in a vacuum) } \rightarrow \text { E P. }\end{array}$ \\
\hline Rimmed & $920^{\circ} \mathrm{C}, 1 \mathrm{hr}$, F.C. $\rightarrow$ Machining $\rightarrow$ \\
steel (RA) & $700^{\circ} \mathrm{C} .1 \mathrm{hr}$, F.C (in a vacuum) $\rightarrow$ E P. \\
\hline Rimmed & $920^{\circ} \mathrm{C} .1 \mathrm{hr}$, A.C. $\rightarrow 700^{\circ} \mathrm{C}, 1 \mathrm{hr}, \mathrm{W} . \mathrm{Q} . \rightarrow$ \\
steel (RQ) & Machining $\rightarrow$ E.P. (keep at $\left.-10^{\circ} \mathrm{C}\right)$
\end{tabular}

E.P.: Electro-polishing

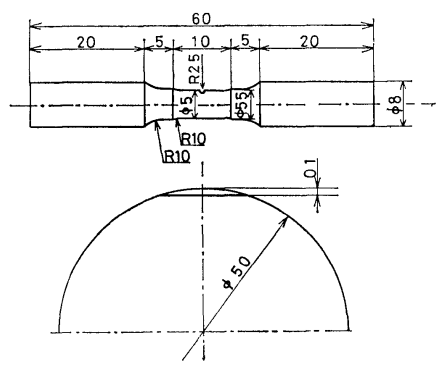

Fig. 1. Dimensions of specimen.
の存在を考えない公称応力で表してある. 試験片はす ベて実験前に表面層を $20 \mu \mathrm{m}$ 以上電解研摩で取り除 いている.なお， CH10R の $0{ }^{\circ} \mathrm{C}$ 水中に焼入れした試 験片の夕は常温に和ける時効硬化の進行を抑えるため 実験の直前までー $10^{\circ} \mathrm{C}$ に保存した。

用いた試験機は小野式回転曲 げ疲労試験機（容量 $1.5 \mathrm{~kg} \cdot \mathrm{m}, 3000 \mathrm{rpm})$ である.

疲労過程を連続的に観察するため, 応力繰返しの途 中でとさどき試験機を止め, 切欠き部からレプリカを 採取した. そのレプリカから作製した試料について, き裂発生の起点を金属顕微鏡放よび走査電子顕微鏡で 観察した。また破面観察はき裂伝ぱの途中で未破断部 を液体窒素中でぜい性破壊させたのち，SEM を用い て行った.

\section{3 実験結果および考察}

\section{$3 \cdot 1$ 疲労挙動に及ぼすひずみ時効の影響とき裂発 生過程}

Fig. 2 に各材料の $S-N$ 曲線とき裂発生曲線を示す. ここでき裂発生繰返し数とは 1 結晶粒程度のき裂が隣 りの結晶中に伝ぱし始めるのが確認された繰返し数で ある、焼なましした CH10A， CH10R および低温焼 入れした $\mathrm{CH} 10 \mathrm{R}$ (以後それぞれ $\mathrm{AA}$ 材, RA 材沶よ び $\mathrm{RQ}$ 材と呼ぶ）の疲労限度はそれぞれ $15.5,15.0$ 特よび $23.0 \mathrm{~kg} / \mathrm{mm}^{2}$ である. $\mathrm{RQ}$ 材は他の材料と比 べて約 $50 \%$ 疲労限度が高く, $S-N$ 曲線のこう配も多 少大さいようであり, また折れ点も比較的早くから明 りょらに現れて沶り，従来の報告と同傾向を示してい る.さらにこの図から破断寿命に対するき裂発生寿命 の割合は $\mathrm{RQ}$ 材で約 $10 \%$, AA 材和よび $\mathrm{RA}$ 材で約 $30 \%$ であり, 同一応力振幅, 例觉ば $\sigma_{a}=23 \mathrm{~kg} / \mathrm{mm}^{2}$

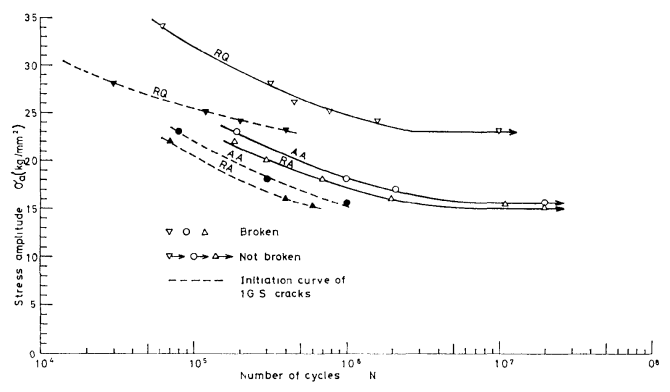

Fig. 2. $S-N$ curves and initiation curves of one grain size crack.

Table III. Mechanical properties.

\begin{tabular}{c|c|c|c|c|c}
\hline Material & $\sigma_{S l}\left(\mathrm{~kg} / \mathrm{mm}^{2}\right)$ & $\sigma_{B}\left(\mathrm{~kg} / \mathrm{mm}^{2}\right)$ & $\sigma_{T}\left(\mathrm{~kg} / \mathrm{mm}^{2}\right)$ & $R$ of $A(\%)$ & $H_{V^{*}}$ \\
\hline Al-killed steel (AA) & 17.4 & 34.5 & 69.7 & 69.4 & 89 \\
Rimmed steel (RA) & 202 & 32.1 & 85.0 & 77.1 & 86 \\
Rimmed steel (RQ) & 28.2 & 42.7 & 112.6 & 77.6 & 127 \\
\hline
\end{tabular}

* 1000 gr. $30 \mathrm{sec}$. 
でさ裂発生寿命を比較すれば，RQ 材は他の材料の約 5 倍方る. 以上のことから定量的には時效硬化能の最 6大きい $\mathrm{RQ}$ 材 $\mathrm{AA}$ 枌, $\mathrm{RA}$ 材に比べてき裂発生 だけでなく，伝ぱに対する抵抗るかなり大さいことが 为かる。

Fig. 3 は疲労限度より約 $50 \%$ 高い応力を少数回繰返 すとさの表面に和けるすべり带とき裂の発生状熊を示 す乎ので，AA 材ではすべり帶は密に結晶粒を好りつ ぶすように発生するのに対 $\mathrm{L}, \mathrm{R} Q$ 材では粒内に離散 的に発生する。この傾向は疲労限度付近の応力老繰返 す場合にも認めら机，また從来の報告とも一致する。

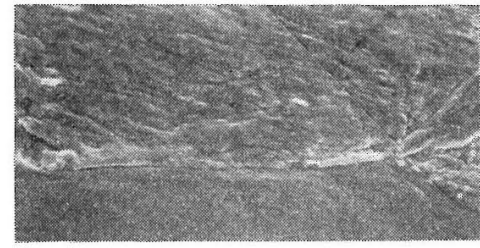

(a) Al-killed steel (AA),

$\sigma_{\mathrm{a}}=23.0 \mathrm{~kg} / \mathrm{mm}^{2}, \quad N=5 \times 10^{4}$

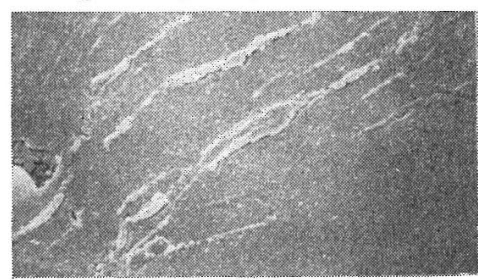

(b) Quenched rimmed steel ( $R Q$ )

$\sigma_{a}=34 \mathrm{~kg} / \mathrm{mm}^{2}, N=10^{4}, 5 \mu \mathrm{m}$

Fig. 3. SEM micrographs of slip bands and fatigue microcracks.
Fig.4，5，7 は先れ艺机 AA 材，RA 材， RQ 材 に疲労限度より高い応力を繰返すときのき裂発生の起 点を含虫表面状態の変化示したもので，Fig. 6 は Fig. 5 の黑枠部の SEM 写真である. Fig. 8 は RQ 材のき裂発生部の SEM 写真であり, Fig. 3(b) と同一 䇢所で常る。裂発生箇所怔多くの場合，AA材，RA 材では粒界に沿う部分であるのに対し，RQ 材ではす

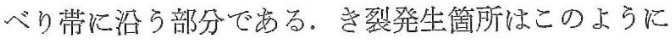
材料によって異るようであるが，严裂発生過程の定性

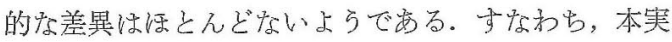
験の範囲では既報に和けると同样に，この過程はどの

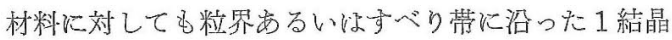
精程度の領域を単位として進行しているようで㐫る。

Fig. 9 はこの過程を模式的に示したすので， 1 結晶䊀 程度の将来き裂となるべき領域（粒界岕るいはすべり

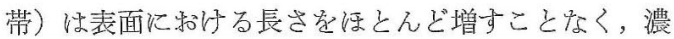

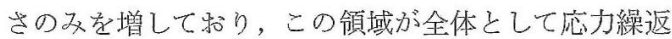
しとともに徐々に疲労被害を受けてき裂に近づいてい るようである。したがって，この過程にはき裂伝ば特 性は含まれないことになる。1 結晶粒程度のき裂が発 生した後にはき裂が応力，ひずみの集中源となり，き 裂先端付近飞集中的に疲学被害加篦積されてき裂以伝 ぱする，以上の過程は $\mathrm{AA}$ 材， $\mathrm{RQ}$ 材江疲学限度の応 力を繰返す場合にも認好らた $(3 \cdot 3$ 節参照 $)$.

\section{$3 \cdot 2$ 初期疲学破面の観察}

Fig. 10，11 は乞それそれ RA 材，RQ 材の初期痩労 破面の SEM 写真である. RA 材では粒界に，RQ 材 ではすべり帯に沿ってき裂が発生している。どの場合

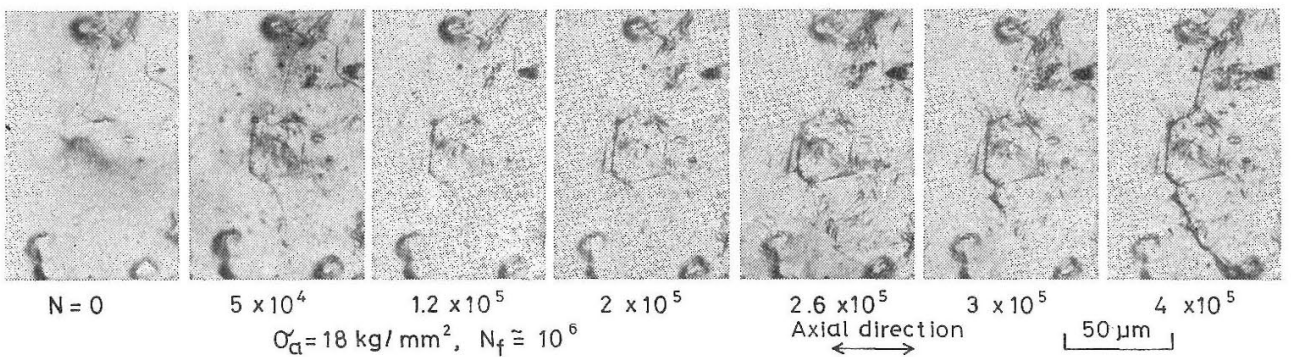

Fig. 4. The change in surface of an annealed aluminum-killed steel (steel AA).

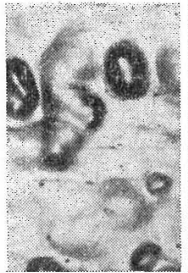

$N=0$

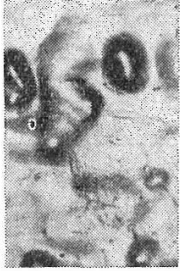

$5 \times 10^{3}$

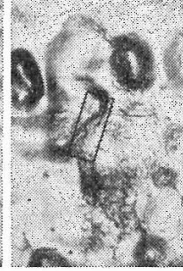

$1.5 \times 10^{4}$

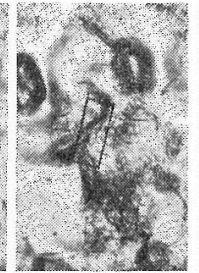

$3 \times 10^{4}$

$\sigma^{\prime} a=22 \mathrm{~kg} / \mathrm{mm}^{2}, \mathrm{Nf} \cong 1.8 \times 10^{5}$

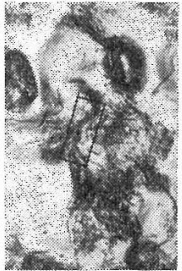

$6 \times 10^{4}$ Axial direction

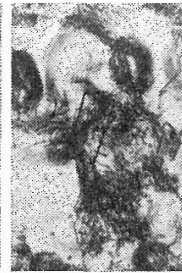

$1 \times 10^{5}$

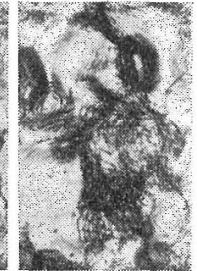

$1.2 \times 10^{5}$

$50 \mu \mathrm{m}$

Fig. 5. The change in surface of an annealed rimmed steel (steel RA). 


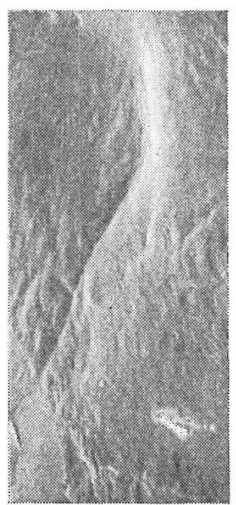

$N=1.5 \times 10^{4}$

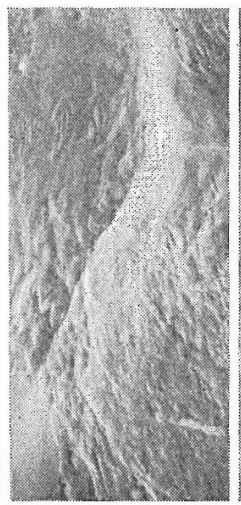

$3 \times 10^{4}$

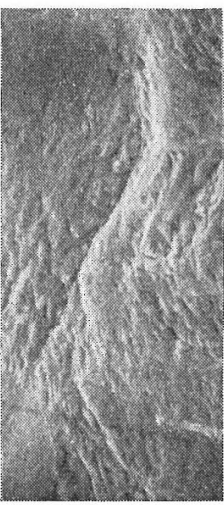

$6 \times 10^{4}$

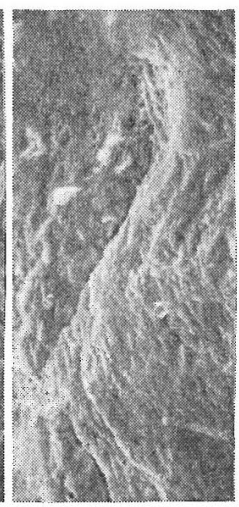

$1 \times 10^{5}$

Fig. 6. SEM micrographs of the specimen surface, black framed parts in Fig. 5.

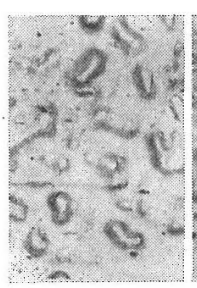

$N=0$

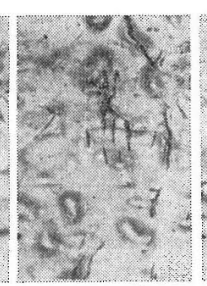

$5 \times 10^{4}$
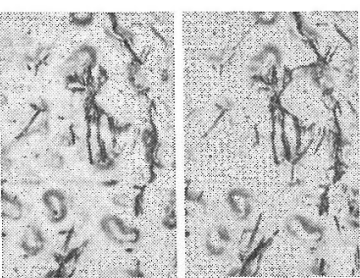

$1.2 \times 10^{5}$

$2 \times 10^{5}$

$$
\sigma_{\mathrm{a}}=25 \mathrm{~kg} / \mathrm{mm}^{2}, N_{f} \cong 8 \times 10^{5}
$$
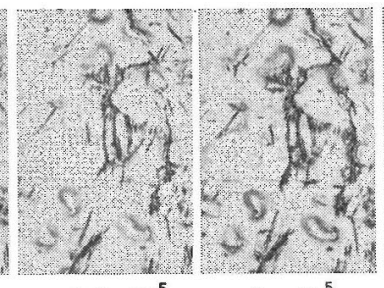

$$
2.5 \times 10^{5} \quad 3 \times 10^{5} \quad 4.4 \times 10^{5}
$$

Fig. 7. The change in surface of a low temperature quenched rimmed steel (steel RQ).

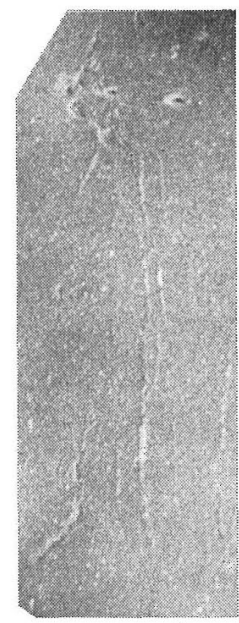

$N=2 \times 10^{3}$

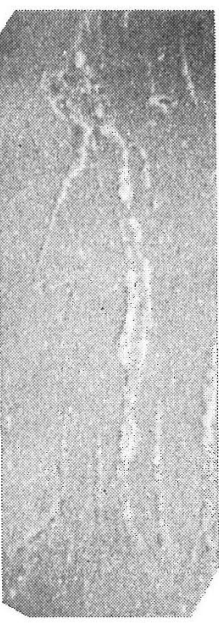

$5 \times 10^{3}$

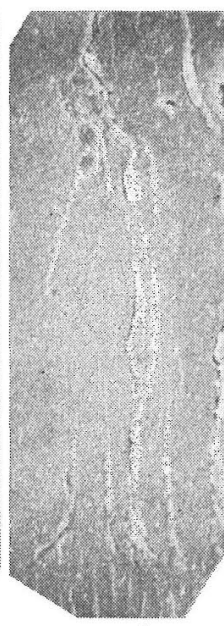

$1 \times 10^{4}$

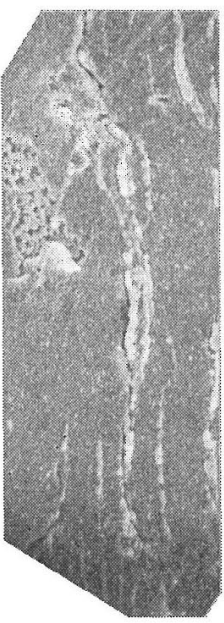

$1.5 \times 10^{4}$

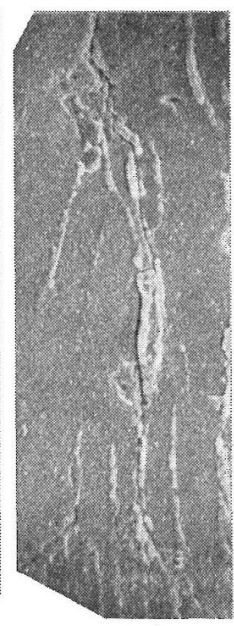

$2 \times 10^{4}$

Fig. 8. SEM micrographs of the surface of a low temperature quenched rimmed steel (steel $R Q$ ).

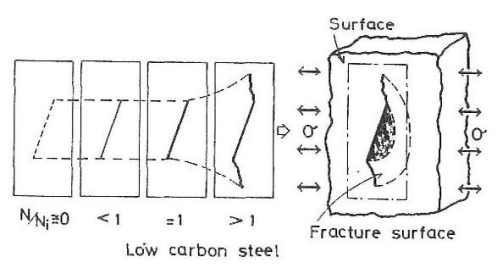

Fig. 9. Schematic illustration of the crack initiation process.
にも 1 結晶粒程度の領域（矢印家付引た部分）は比較 的平たんであり，3・1 節で述べたき裂発生過程を反 映しているよらに見觉る。すなわちこの領域内の各部 分の様相は互いによく似て爫り，しかも1結晶粒さ裂 発生後のき裂伝ば過程に対応する破面にはこの領域内 に和けるような破面の椂相は認められなかった。した がってき裂発生部の破面索帅成寸る過程はき裂の伝ぱ

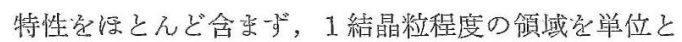




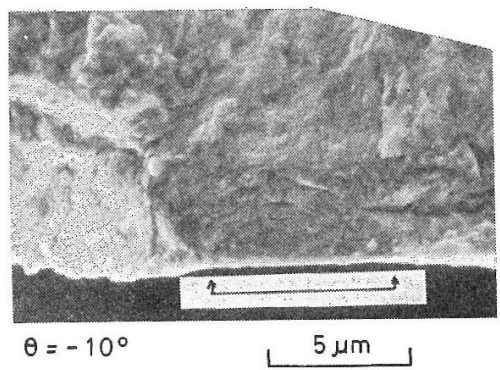

Fig. 10. A fractograph of the crack initiation region, an annealed rimmed steel (steel RA), $\theta$ is the angle between the direction of the specimen axis and that of the incident clectron beam.

して徐及にき裂に近づく過程に相当するものと思われ る。な和，本材料では大塚らが報告している低炭素鋼 のせん断型き裂面の平行な線状パターンの確認は困難 で㐫った。

\section{$3 \cdot 3$ 微視的停留き裂}

Fig. 12，13 はそれぞれ $\mathrm{AA}$ 材， $\mathrm{RQ}$ 材に疫労限度 の応力を $10^{7}$ 回以上繰返すとき観察された，数結晶に

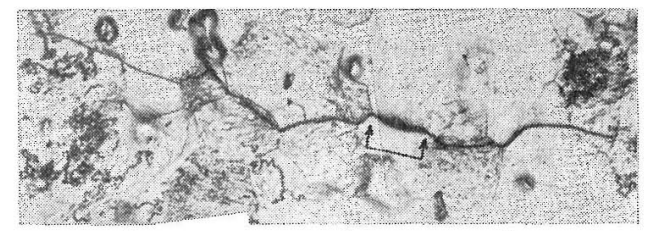

(a) $\sigma_{a}^{\prime}=\sigma_{w}=15.5 \mathrm{~kg} / \mathrm{mm}^{2}, N=1.3 \times 10^{7}$
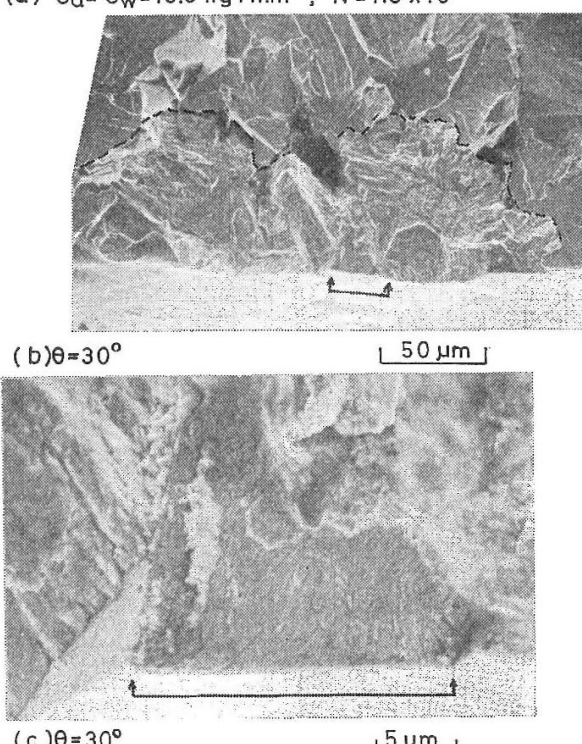

(c) $\theta=30^{\circ}$

$5 \mu \mathrm{m}$

Fig. 12. A non-propagating microcrack of an annealed aluminum-killed steel (steel AA), $\theta$ is the anglc between the direction of the specimen axis and that of the incident electron beam.

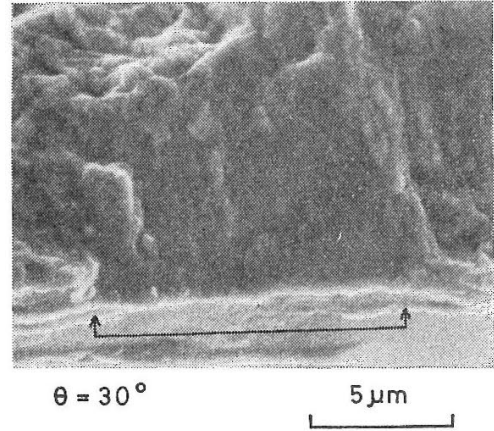

Fig. 11. A fractograph of the crack initiation region, a low temperature quenched rimmed steel (steel RQ), $\theta$ is the angle between the direction of the specimen axis and that of the incident electron beam.

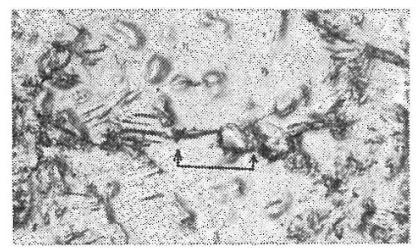

(a) $\sigma_{\mathrm{c}}=\sigma_{\mathrm{m}}=23 \mathrm{~kg} / \mathrm{mm}^{2}, \mathrm{~N}=10^{7}$
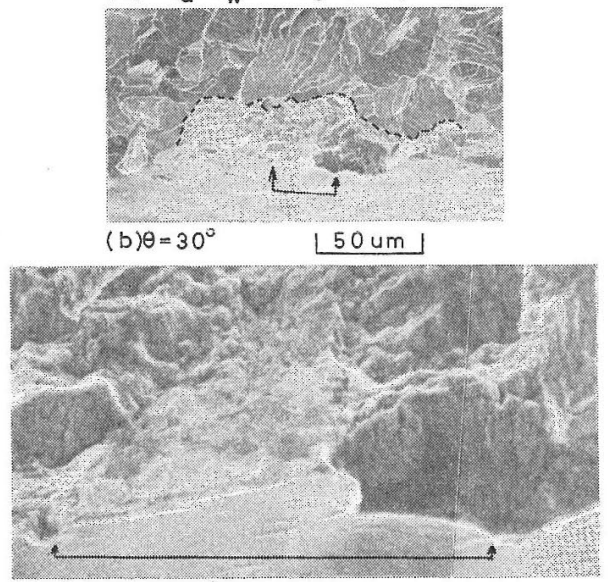

(c) $\theta=30^{\circ}$

$5 \mathrm{um}$

Fig. 13. A non-propagating microcrack of a low temperature quenched rimmed steel (steel $\mathrm{RQ}$ ), $\theta$ is the angle between the direction of the specimen axis and that of the incident electron beam.

及ぶ微視的停留き裂の表面就よび破面写真である。 Fig. 12 (c)，13 (c)加らわかるようにき裂発生部の破面 は前述のき裂発生過程の特微を反映している。これら のことから，AA 材， RQ 材に打当痩労限度は，発 生した 1 結晶粒程度のき裂が表面に沿らだけでなく， 内部に向って多少伝ぱしたのb停留する限界の応力 であると言える。Fig.14 (a)，(b)は艺れ艺れ Fig.12， 13 と同一試験片に発生した 1 結晶粒程度の粒界および すべり带に沿うき裂でむる（知印部）。このょらに疲 


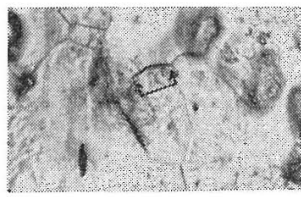

(a) $\sigma_{w}=15.5 \mathrm{~kg} / \mathrm{mm}^{2}$

Fig. 14. Non-propagating microcracks remaining within one grain under fatigue limits.

労限度では，1結晶粒程度で留劣るき裂もかなり認め られるが，最大のき裂に注目すれば $A A$ 材，RQ 材で はほとんどの場合，1結品粒を越光て伝ぱしたのち停 留する過程が認められるのが普通である。

さきに著者の一人は，炭素鋼のコーキシング効果は， 微視的停留き裂の先端部の加工硬化とひずみ時效によ る強化作用を通じて現れることを指摘している。 RQ 材のような低温焼入れによってひずみ時效能が高めら れた材料では，疲労限度に婄いて発生した微小き裂が 低速度で伝ぱしているとき，き裂先端付近のひずみ時 效による強化作用が他の材料に比べてかなり人きいた め，き裂伝ぱ抵抗の增大の割合も他の材料より大きく （疲労限度上り高い応力学繰返す場合にも $3 \cdot 1$ 節て 述べたよらに全寿命に占める伝ぱ寿命の割合が他の材 料より大きい)，き裂が停留しゃすくなるものと思わ れる.このことはひずみ時効能の高い材料はコーキシ ング效果る蹎著であることとも関連があるものと思わ れる。

\section{4 結 ，論}

ひずみ時効能の異る 3 種の低炭素鋼，焼なましした CH10A，CII10R 煔上び低温焼入れした CH10R の回

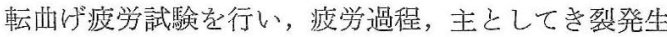
過程に及注すひずみ時効の影響を電顕連続観察呿上び 破面観察を通じて検討し，以下の結論学得た。

（1）き裂発生簀所が粒界（焼なまし材）あるいはす ベり带（低温燒入れ材）と材料によって異るが，き裂 発生過程の材料間の定性的な差異は活とんど認められ ない.この過程は 1 結晶粒程度の有限な領域が㡰力繰 返しとともに全体としてき裂に近つく過程であり，そ の後の伝ぱ過程とは本質的に異为。また破面観察から もこのことを支持する情報が得られた。ひずみ時效能 の最も高い低温焼入れ材では他の材料に比べてき裂発 生に刘する抵抗も大きいが，それ以上にき裂伝ぱに対 する抵抗が大きく，疲学限度山他の材料より約50\%高 W.
（2）疲労限度の応才を $10^{7}$ 回以上繰返して認められ る微視的停留き裂の中には 1 結晶粒内に留委るむのb あるが，最大のものは1結晶粒を越えて表面に沿って もまた内部に向っても多少伝ぱしたのら停留するのが 普通である。

終りに，供試材 (CH10A，CH10R) についてご便宜 を頂いた疲学部門委員会田中道七委員長に感謝申し上 げます。またひずみ時効に関して貴重なご助言を下さ った九州産業大学，田中哲志講師和よび実験の遂行に 当り協力された佐賀大学埋工学部，伊藤勝美技官に感

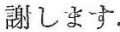

（昭和54年11月 7 日 第13回疲労シンポジウムにて講演）

\section{参 考 文 献}

1) 広瀬素尚, 長谷川舆彦, 加藤容三，宮田丈太郎，材料， 25, 851 (1976).

2）小林英男，川出幸男，中沢 一，材料，25，881 (1976)。

3) 北川 茂, 日本材料学会筑10回シンポジウム前刷集, 68 (1976).

4) 戸梶恵郎, 安藤善司, 牛田雅己, 朝原 j, 材料, 25, 863 (1976).

5) 戸梶恵郎, 安藤善司, 牛田雅己，材料， 26，1218(1977)。

6) 中川隆夫, 日和千秋, 日本材料学会第12叫疲学シンポジ ウム前刷集, 70 (1978).

7）西谷弘信，田中哲志，戸高 健，日本材料学会第12回痩 労シンポジウム前刷集, 6 (1978)

8）山田敏郎，幡中憲治，近藤幸夫，河合 宏，材料， 25 , 857 (1967).

9）広瀬素尚，脣谷川典彦，加藤容三，材料， 27, 841 (1978).

10）日本材料学会疲労部門委員会サブグループ I，材料，27, 908 (1978)

11）西谷弘信，田中哲志，日本機悈学会講演論文集，No. 780-13, 189 (1978).

12）成本朝雄, 小林邦彦, 田中康浩, 船越督己，材料，25, 846 (1976).

13）西谷弘信，高尾健一， 日本機械学会論文集，40，3254 (1974).

14）高尾健一，西谷弘信， 日本機械学会論文集，46，A， 123 (1980).

15）大塚昭夫，森＼cjkstart要，第22回材料強度之破壤国内シンポ ジウム論文集，1（1977）。

16) 高尾健一，西谷弘信，材料，28，873 (1979).

17）西谷弘信，西田新一，日本機械学会論文集，39，1385 (1973). 